\title{
МИРОВОЗЗРЕНИЕ ВАСИЛИЯ ШУЛЬГИНА В КОНТЕКСТЕ СОБЫТИЙ 1917-1919 ГГ. В КИЕВЕ
}

\section{ŚWIATOPOGLĄD WASILIJA SZULGINA W KONTEKŚCIE WYDARZEŃ LAT 1917-1919 W KIJOWIE \\ THE WORLDVIEW OF VASILY SHULGIN IN THE CONTEXT OF THE EVENTS OF 1917-1919 IN KIEV}

\author{
Antoni Bortnowski \\ Uniwersytet im. Adama Mickiewicza, Poznań - Polska, \\ a.bortnowski@amu.edu.pl
}

\begin{abstract}
Vasily Shulgin (1878-1976) was a Russian political activist of the beginning of the $20^{\text {th }}$ century. He is also known as an active publicist and the author of several memoir books. Born in Kiev and considering himself a "little-Russian", Shulgin acted as a supporter of the unity of Ukraine and Russia and considered his native city as the cradle of "Russianness" as well as an integral part of the whole-Russian cultural circle. Shulgin's worldview, reflected in his memoirs devoted to the years 1917-1919, became the subject of this article.

Ключевые слова: Василий Шульгин, мемуары, Гражданская война в Киеве, киевский текст, русские киевляне.

Słowa kluczowe: Wasilij Szulgin, memuary, wojna domowa w Kijowie, tekst kijowski, rosyjscy kijowianie.

Keywords: Vasily Shulgin, memoirs, civil war in Kiev, Kiev text, Russian Kievans.
\end{abstract}

Ровно сто лет назад территории уже рухнувшей Российской империи находились в самом разгаре колоссальных исторических потрясений, которые определили и во многом продолжают определять облик всей восточной части Европы, да и не только. Сегодня, уже более четверти века после распада СССР, оценки событий столетней давности не только не удалось привести к общему знаменателю, но местами они продолжают „растекаться” в противоположных направлениях. Попытки манипулировать прошлым, грубо обозначать четкие границы не только политических, но и духовных, культурных „сфер влияния" неоднократно приводят к искажениям многих понятий и формированию выборочной и даже ложной исторической и культурной памяти. На постсоветском пространстве, в условиях активной фазы формирования национальной идентичности и переосмысления собственной истории, попытки заново рас- 
ставить акценты или умолчать о не вписывающихся в новые реалии исторических лицах или явлениях встречаются довольно часто. Примером в данном случае может стать личность политического деятеля, публициста, мемуариста Василия Витальевича Шульгина (1878-1976), ставшего в какой-то степени олицетворением судьбы дореволюционного, преимущественно русского Киева начала XX столетия 1 .

В советское время Шульгин был забыт по идеологическим причинам, а в условиях независимой Украины стал „чужим” по национальному признаку. Личность Василия Шульгина, сделавшего сознательный выбор в пользу общерусской идентичности, но вместе с тем подчеркивающего исключительность (а иногда и превосходство) родного Киева по отношению к Петербургу и Москве, доказывает, что присутствие русской культуры на Украине не может оцениваться только как результат насильственной русификации и грубой имперской политики царских властей. Неудивительно, что творчеством Шульгина занимаются сегодня в основном российские ученые. К сожалению, в их работах Шульгин чаще всего рассматривается как „общерусский” деятель, а его „киевоцентризм” отдельно не изучается 2 . В данной статье мы постараемся сосредоточиться прежде всего на необычном с сегодняшней точки зрения мировосприятии человека, для которого понятия „киевлянин” и „русский” органично дополняли и даже усиливали друг друга.

Василий Витальевич Шульгин родился в 1878 г. в Киеве, в семье, которую, безусловно, можно назвать „местной”3. Происхождение будущего политического деятеля не дает оснований некоторым современным украинским деятелям культуры называть его „чужерод-

1 Согласно переписи населения Киева, проведенной в 1917 году, русские составляли в городе 54,73\%, а украинцы - 12,21\%. См. А. Пученков, Национальный вопрос в идеологии и политике южнорусского Белого движения $b$ годы Гражданской войны. (1917-1919 ге.), Санкт-Петербург 2005, с. 57.

2 См.: А. Репников, В. Христофоров, В. В. Шульгин - последний рыцарь самодержавия. Новые документы из архива ФСБ, „Новая и новейшая история” 2003, № 4; Г. Иоффе, Василий Шульгин, „Новый журнал” 2006, № 242-243; Д. Бабков, Государственные и национальные проблемы в мировоззрении В. В. Шульгина в 1917-1939 годах, Москва 2012 и др.

3 Упоминания об исконно украинском происхождении рода Шульгиных встречаются редко, но вот двоюродный брат Василия Витальевича, историк Яков Николаевич, прямо называется „потомком древнего казацкого рода”. См. Провiдники дyховності в Украӥні, ред. І. Ф. Курас, 2003, [в:] электронный ресурс: https:// uchebnikionline. com/kulturologia/providniki_duhovnosti_v_ukrayini_-_kuras_if/shulgin_yakiv_ mikolayovich.htm (27.01.2018). 
ным" элементом, засланным для русификации Юго-Западного края Российской Империи, как и в случае писателя Михаила Булгакова ${ }^{4}$.

Шульгин с самого начала жизни был тесно связан с Киевом: окончил Вторую киевскую гимназию5, затем юридический факультет Киевского университета Святого Владимира. С 1906 года Василий Шульгин включается в общероссийскую политику и становится представителем Волынской губернии в Государственной думе. За последнее десятилетие существования Российской Империи, несмотря на свои правые и монархические убеждения, известный киевлянин начинает склоняться к оппозиции. Окончательно Шульгин убеждается в губительности политического курса царских властей в годы Первой мировой войны. Побывав добровольцем на фронте и увидев тысячи ненужных жертв, ставших, по его мнению, результатом недальновидной российской политики, главный редактор „Киевлянина” возвращается в Петербург и уходит в твердую оппозицию. В 1917 году Шульгин присутствует при отречении Николая II на станции Дно, а затем отправляется в Киев.

В родном городе политический деятель предпринимает активные попытки консолидировать ряды единомышленников и противостоять одновременно и социалистам, и украинскому национальному движению. Свою борьбу Шульгин вел не только на страницах редактируемого им „Киевлянина” - летом 1917 года возглавляемый им блок участвовал в выборах в городскую думу. Получить власть в родном городе не получилось, но третье место и свыше 14\% голосов 6 для монархиста, выступающего за продолжение войны против Германии, - результат весьма внушительный. В годы гражданской войны Шульгин стал активным участником Белого движения и в конще 1919 года вместе с армией Деникина направился из Киева в Одессу, а затем прошел известный многим эмигрантам для многих эмигрантов путь через Крым и Константинополь на Запад. Проживая в Югославии, Василий Шульгин в 1925-1926 гг. тайно посетил СССР (одной из причин были поиски погибшего уже к тому

${ }^{4}$ Известная украинская писательница Оксана Забужко называет автора Белой гвардии „понаехавшим” квартирантом, сыном батюшки-цензора, прибывшего с Орловщины „на доплату за обрусение края”. См.: О. Забужко, Цей проклятий „квартирный вопрос", [в:] электронный ресурс: https://www.radiosvoboda.org/a/27079412.html (27.01.2018).

${ }^{5}$ В отличие от киевлян-современников Шульгина, Михаила Булгакова и Константина Паустовского, учившихся в более престижной Первой мужской гимназии.

6 Группа Шульгина уступила социалистическому списку (37\%) и списку украинских социалистов (20\%), см.: Р. Красюков, Примечания, [в:] В. Шульгин, Тени, которые проходят, Санкт-Петербург 2012, с. 586. 
времени сына Вениамина), побывав также в родном Киеве. В конце 1944 года, после прихода на Балканы Красной армии, бывшего редактора „Киевлянина” арестовали, вывезли в СССР и за активную антисоветскую деятельность приговорили к 25 годам тюрьмы. В 1956 г. Шульгин был досрочно освобожден и остался жить во Владимире, куда к нему из Югославии приехала жена. Умер известный киевлянин в 1976 г. на 99-м году жизни.

Главной сферой деятельности Василия Шульгина, кроме политики, была публицистика, хотя он создал также ряд художественных произведений, например цикл исторических романов о приключениях волынского князя Воронецкого. Свои убеждения политический деятель высказывал главным образом на страницах газеты „ККиевлянин”, главным редактором которой являлся с 1913 по 1919 год. Идейная позиция издания с момента основания его отцом Василия Шульгина оставалась неизменной и заключалась, главным образом, в отстаивании „общерусскости", понимаемой как духовное единство России и Украины. Об этом упоминает сам Василий Витальевич:

Виталий Яковлевич [отец Василия Шульгина - А.Б.] [...] посвятил себя... публицистической трибуне, основав в 1864 году газету „Киевлянин”. Это было вскоре после польского восстания, почему первая передовая статья „Киевлянина” начиналась словами: „Этот край русский, русский, русский...”, и эта традиция продолжалась до самого конца издания газеты. Сначала защищали южнорусский край от поляков, затем от украинствующих. Однако от евреев не защищали, потому что никто их всерьез не принимал (34)7.

Кстати, мнение (особенно распространенное в советское время) об антисемитизме „Киевлянина” и самого Шульгина ${ }^{8}$, а также об абсолютной лояльности издания царским властям не до конца соответствует правде. На страницах газеты появлялись осуждения еврейских погромов, слова защиты в адрес Дрейфуса, а также Бейлиса, киевского еврея, несправедливо обвиняемого в ритуальном убийстве. Независимость своей позиции „Киевлянин” доказал после Февральской революции, оставшись верным своим многолетним принципам9.

7 В. Шульгин, Тени, которые проходят, Санкт-Петербург 2012, с. 34 . В дальнейшем цитаты по данному изданию будут приводиться с указанием номера страницы в скобках.

8 Шире специфику отношения Шульгина к евреям обсуждает Генрих Иоффе. См. Г. Иоффе, Василий Витальевич Шульгин, „Новый журнал” 2006, № 242, [в:] электронный ресурс: http://magazines.russ.ru/nj/2006/242/io15.html (27.01.2018).

9 Данный вопрос более подробно рассматривается в статье Д. Бабкова. См. Д. Бабков, Политическая публицистика В. В. Шульгина В период гражданской войны и эмиграциии, „Вопросы истории" 2008, № 3, с. 92-106. 
Уже в эмиграции Василий Шульгин занялся созданием мемуаров, посвященных главным образом последнему дореволюционному десятилетию и периоду гражданской войны. Воспоминания редактора „Киевлянина" были опубликованы в книгах Годы (1920) - о периоде между революциями 1905 и 1917 года, Дни (1925) - о событиях, предшествующих падению монархии, и 1920 (1921) - последний год гражданской войны. Стоит обратить внимание также на книгу Три столицы (1927), содержащую впечатления от вышеупомянутого „тайного” путешествия в Советский Союз. Особое внимание привлекает многоговорящее заглавие, подтверждающее, что для Шульгина и после революции Киев продолжал оставаться одной из трех столиц, наравне с Москвой и Санкт-Петербургом, уже успевшим к тому времени стать Ленинградом.

Родной город Шульгина в воспоминаниях, относящихся к историческим потрясениям столетней давности, занимает особое место. Интересно, что изначально „киевский период” Гражданской войны в его мемуарах был пропущен - Дни заканчиваются с началом революции, а 1920 начинается прибытием в Одессу, куда Шульгин попал после потери белыми Киева. Данный „пробел” был заполнен только в начале 70-х, хотя киевский период Гражданской войны был, безусловно, ключевым для Шульгина. На этот момент обратил внимание Ростислав Красюков в предисловии к книге воспоминаний: „Меня наиболее интересовал период его [В. Шульгина - А. Б.] пребывания в советской тюрьме. Но „Дед” был непреклонен, в первую очередь он хотел работать над воспоминаниями о Гражданской войне" (13).

Именно Красюкову Василий Шульгин продиктовал в течение нескольких месяцев 1970 г. воспоминания, впоследствии опубликованные в альманахе „Лица” в 1994 году под названием 1917-1919. Интересно, что, несмотря на полстолетия, отделявшие тогда 92-летнего Шульгина от киевских событий, политический деятель был в состоянии восстановить не только исторический, но и житейский пласт того времени.

Его память цепко держала последовательность событий и имена лиц, участвовавших в них, как будто это произошло не полвека назад, а всего лишь вчера. Кроме того, он был неисчерпаемым рассказчиком всевозможных житейских историй, случаев и анекдотов (13).

Особенностью воспоминаний Василия Шульгина является их удивительная идейная последовательность, которая видна при сравнении мемуаров 70-х гг. с текстами статей, написанных в „Киевлянине” еще до революции, и работ, созданных уже в эмиграции. Даже в советских реалиях Шульгин оставался верным своим убеждениям, не пытаясь вписываться в актуальную „конъюнктуру” (что, впрочем, понятно, учитывая преклонный возраст автора). 
Кроме преданности своим идеалам постоянно появляющимся элементом в текстах Шульгина становится „киевоцентризм”, отражающий особую, эмоциональную связь с родным городом. Редактор „Киевлянина” неоднократно прямо писал о своей привязанности к „матери городов русских", вот один из примеров:

Ведь родина, это, прежде всего, тот уголок, среди которого мы выросли, где мы провели наши лучшие годы... Ведь для нас родина - это, прежде всего, - Киев, Киев, из глаз которого смотрит на нас прошлое, темное, волнующее, таинственное, прекрасное ${ }^{10}$.

Данный фрагмент показывает также типичное для Шульгина переплетение личного с общенациональным. Другим характерным для мемуариста сочетанием стало перекликание „киевского” с „общерусским”, как, например, в словах „И вот, наконец, Киев! „Как много в этом звуке...”", (251). Эта фраза относилась к восторгу Шульгина, прибывшего в Киев на первом поезде, сразу после взятия города Добровольческой армией генерала Деникина в августе 1919 г. Приведенные слова, отсылающие к строкам Евгения Онегина11, не только подчеркивают самоидентификацию Шульгина, но и в какой-то степени указывают на неразрывность Киева и русского культурного пространства. Заменяя Москву в словах Пушкина Киевом, Шульгин подчеркивает, что для русского человека древняя столица Руси может быть не менее (а возможно, и более) важной, чем первая столица России.

Василий Шульгин, даже пребывая в Санкт-Петербурге в качестве депутата Государственной думы, не терял киевской перспективы событий. „Киевское мировоззрение перенесено было на север” (142), - вспоминал Шульгин свой переезд в столицу. Находясь вдалеке от Киева, он не раз подчеркивал свою тоску по родным сторонам и близким ему людям. Вот, например, слова обращения к читателям „Киевлянина”, отправленные по телеграфу к Пасхе 1917 года:

В день Святого Праздника особенно хотелось бы быть близко к тем, кто столько лет связан духовными нитями с „Киевлянином”. Прикованный к Петрограду, не ощущая на себе дыхания родного края, чувствуешь какую-то пустоту, не зная, что думают и о чем волнуются люди родственного понимания и близких взглядов" 12 .

10 В. Шульгин, Украина, „Киевлянин” 1912, № 4. Здесь и далее орфография и пунктуация автора сохранены - А. Б.

11 Ср.: „Москва... как много в этом звуке// Для сердца русского слилось! // Как много в нем отозвалось!" - А. Пушкин, ЕВгений Онегин, [в:] Его же, Сочинения 6 трех помах, т. 3, Москва 1978, с. 131.

12 В. Шульгин, Дорогие читатели!, „ККиевлянин” 1917, № 89. 
Из данного фрагмента вытекает, что и в столице Империи Шульгин чувствовал себя прежде всего киевлянином, „прикованным к Петрограду" в силу своей политической деятельности. Симптоматично, что даже воспоминания, абсолютно не касающиеся политических событий, часто приобретают у Шульгина киевскую окраску. Вот каким образом мемуарист описывает красоту своей любовницы Екатерины Сухомлиновой:

Если Екатерина Викторовна Сухомлинова ${ }^{13}$ была васнецовское дитя во Владимирском соборе Киева, то эта смолянка имела глаза Богоматери, которая держит в руках этого младенца (244).

Впрочем, также рассуждения на политические темы, не касающиеся родного города (как например вопрос смертной казни), у Шульгина получали неоднократно киевский подтекст:

Мне вспомнился Владимир, князь Киевский, святой и равноапостольный. Он принял христианство по-настоящему и прекратил смертную казнь. Но дело повернулось плохо. Киев стал голодать, потому что прекратился подвоз продовольствия. А это случилось потому, что разбойники обнаглели. И народ киевский стал открыто говорить, что прежняя вера была лучше (232).

Василий Шульгин воспринимал себя не как человека, распространяющего влияние России на территорию Украины, а как представителя Малороссии, отстаивающего в Санкт-Петербурге ее интересы. Рассуждения на тему взаимосвязи России и Украины однозначно указывают на специфику мировоззрения Шульгина, „переворачивающую" традиционное восприятие центра и периферии Российской Империи:

Мы дважды русские, потому что мы из Киева - матери городов русских, потому что Москва и Петроград - колонии Киева, а не наоборот. [...] Метрополиями всегда называлась сердцевина народа, и в то же время называлась „малая". Например, Малая Русь по отношению к Великой Руси и Малая Бретань по отношению к Великой Британии (155).

Исходя из убеждений Василия Шульгина, подчеркивающих преемственность Киевской Руси и России, Киев („мать городов русских") рассматривается как колыбель всего русского, город, без которого Москва и Санкт-Петербург останутся лишь колониями, лишенными своей метрополии, своих истоков. В этом контексте становится понятно, почему украинская национальная идея, настаива-

13 Екатерина Викторовна Сухомлинова, одна из самых известных „светских львиц" дореволюционной России. Именно с нее художник Виктор Васнецов писал Младенца Христа в киевском Владимирском соборе. См. Л. Лурье, Бедная Катя, „Городское обозрение \& Галерея красивых домов и квартир" 2011, № 2, [в:] электронный ресурс: http://gorod.spb.ru/articles/1305 (27.01.2018). 
ющая на „чужеродности” всего русского в Киеве, рассматривалась Василием Шульгиным и его единомышленниками как главная угроза. Кстати, намного более опасная, чем большевизм.

События, разворачивающиеся в Киеве начиная с конща 1917 г. стали для Шульгина временем, когда прежде всего решался вопрос о будущей национальной идентичности города и отношения его жителей к историческому наследию:

Они [киевляне - А. Б.] должны были решить вопрос, считает ли себя Киев, по завещанию вещего Олега, матерью городов русских и, по наименованию Богдана Хмельницкого, землю вокруг Киева Малой Русью, или же город Кия поплывет по украинствующим болотам, имея преданного анафеме Ивана Мазепу на челе. [...] При таких условиях было очень важно, кого именно Киев изберет в Учредительное собрание (168).

Ситуация, в которой Василий Шульгин был избран представителем Киева в Украинском Учредительном собрании, стала для политического деятеля важным подкреплением его убеждений о „русскости” Киева, даже в ситуации, когда орган, который должен был демократическим путем определить будущее Украины, так и не начал свою работу:

Украинское Учредительное собрание так и не было собрано. Но если бы его собрали, то представителем от „матери городов русских”, то есть столицы Украины Киева, был бы „черносотенец” Василий Шульгин (147).

Стоит обратить внимание, что, отстаивая свое убеждение о „русскости” Киева, Шульгин обращался не только к историческим доводам и наследию Древней Руси, которое и сто лет назад могло многим казаться весьма „неактуальным”. Публицист, например, отвергал украинизацию Киева, проводимую Центральной радой в 1917 году, как акт насильственного насаждения чуждого для горожан языка. В качестве аргумента в пользу своей точки зрения привел любопытную аналогию с Варшавой:

Представим себе, что в Варшаве, когда она была под русским владычеством, были бы запрещены польские издания, и все газеты и журналы должны были бы выходить на русском языке. Представим себе также, что в один прекрасный день этот режим пал. Что произошло бы? - Разумеется, что все варшавские газеты в тот же день вышли бы на родном польском языке. А что произошло в Киеве, когда пали кандалы, сковавшие украинский народ? На следующее утро после объявления свободы вышли ли киевские газеты на родном украинском языке? Ничуть не бывало. Как раньше печатались на русском, так и продолжали печататься по-русски. На русском они выходят и теперь, несмотря на оккупацию края украинцами ${ }^{14}$.

14 В. Шульгин, По телеграфу из Петрограда, „Киевлянин” 1917, № 96. 
Любопытно, что даже сквозь воспоминания о самых активных моментах политической деятельности в Киеве постреволюционного периода периодически „пробиваются" личные реминисценции, в очередной раз подтверждающие сугубо эмоциональное отношение Шульгина к родному городу. Иногда они достигают даже детских впечатлений, как и во фрагменте, описывающем одного „старого знакомого":

Я знал его еще в то время, когда гулял с гувернанткой. Он тогда называл меня попросту Вася. А гувернантка давала ему медную монету, которую он немедленно пропивал. Он был босяк в прямом и переносном смысле. Где скитался зимою, не знаю. Но летом его квартира была в оврагах Царского сада над Днепром. Оттуда был чудный вид на Днепр, а ночью там было небезопасно для всех, кроме босяков. Я понемногу подрастал, а безымянный босяк оставался все тем же. [...] Наступило лето 1917 года. Я иногда проходил мимо Ботанического сада и встречал неизменно босяка. Теперь он почтительно, но радостно меня приветствовал и сообщал важную политическую новость: - Босяки за вас (154).

Шульгин, будучи видным политическим деятелем, в своих воспоминаниях уделяет достаточно много места обыкновенной городской действительности, жизни простых киевлян, к которым редактор „Киевлянина” себя также причислял. Оставаясь в годы Гражданской войны в городе, Шульгин наблюдал и ощущал на себе исторические потрясения вместе с другими горожанами. Поддерживал и навещал своих друзей, проверяя, не пострадал ли кто из них в ходе очередного перехода власти. Одной из наиболее ярких сцен такого типа является описание „прогулки” по Киеву после обстрела и захвата города большевиками в январе 1918 года ${ }^{15}$. Описания бытовых сцен, повседневных забот киевлян в годы Гражданской войны часто переплетаются с неожиданной поэтичностью, как, например, в воспоминании о бесконечных очередях:

Обувь у всех поизносилась и изорвалась. Поэтому, когда магазин „Скороход” объявил продажу обуви, люди бросились к нему. Образовалась до той поры не виданная очередь. Она начиналась у магазина, который где-то был на Крещатике, поднималась по Бибиковскому бульвару до Николаевского парка и обвивала ограду этого сада кольцами в несколько рядов. Очереди стояли и по вечерам, и по ночам. Начинавшие чуточку желтеть каштаны тихо шелестели. В середине, внутри парка, с наступлением темноты собирались толпы народа [...] эти люди теснились на бесчисленных скамьях. Часть из них были люди из очереди, которые отдыхали здесь, оставив смену в оче-

15 См. В. Шульгин, Тени, которые проходят, указ. соч., с. 176-187 (глава 3ахват Киева больмевиками). 
реди, другие были просто любовными парочками. В темноте они обнимались, целовались (151).

Может показаться даже удивительным, что эта столь „живая" картина не только сохранилась полвека в памяти Василия Шульгина, но и попала в работу, посвященную прежде всего осмыслению исторических потрясений, разрушивших дореволюционную Россию. Такое положение вещей, однако, для воспоминаний редактора „Киевлянина" является закономерным. Киевская реальность в его мемуарах - это не просто собрание „сухих" фактов от свидетеля истории, но и красочная панорама жизни того времени, часто с определенной дозой юмора:

Это уже было во времена Скоропадского. Тогда на другом берегу Днепра образовался великолепный пляж, так называемый солярий, который называли голяриумом. Перевозчик Добровольский очень хорошо зарабатывал, перевозя полуголых дам на другой берег. Мы с Васильком [Василид, сын Василия Шульгина - А. Б.] переправились тоже туда на байдарке, но не высадились на голяриум, а поплыли вдоль берега вверх по течению. Так как против течения мы плыли медленно, то внедрились в стаи плавающих дам. Они были очень весело настроены и хватались за байдарку. Василек был скромный юноша, и потому мы пробились без инцидентов (195).

Повествователь постоянно перевоплощается из политического деятеля в обыкновенного человека, для которого Гражданская война имела сугубо личный контекст, став частью семейной истории. Одной из ее трагических страниц стала гибель старшего сына Василия Шульгина, вышеупомянутого Василька. Он оказался в группе 25 юнкеров, получивших приказ защищать Святошинское шоссе от наступающих войск Петлюры и забытых там после бегства из Киева гетмана Скоропадского и военного начальства:

Крестьяне видели, как, втащив на дерево пулемет, они крутили его до последнего патрона. Потом отстреливались из винтовок. Никто не ушел. Все до единого умерли, исполняя приказание. Когда-то, может быть, Россия вспомнит этих бедных детей, которые умирали, пока взрослые предавали. Мать откопала тело его из общей могилы-ямы. Лицо было спокойно и прекрасно, пуля попала прямо в сердце, и, должно быть, смерть была быстрая ${ }^{16}$.

Бессмысленная гибель группы юнкеров, брошенных начальством, стала словно прообразом эпизода из Белой гъардии (1925) Михаила Булгакова, описывающего столкновение „забытого” отряда

16 Письмо В. Шульгина В. Степанову от 6 (19) января 1919 г. Цит. по кн.: В. Бортневский, Неизвестный автограф В. В. Шульгина, [в:] электронный ресурс: http://xxl3.ru/ kadeti/pomnim3.htm\#shulgin (27.01.2018). 
Най-Турса с входящими в город петлюровцами. Подобных „совпадений" в воспоминаниях Шульгина и романе Булгакова можно найти намного больше, что подтверждает их значение в качестве своего рода документов (конечно, совершенно разных) постреволюционного времени. Оба киевлянина, например, обратили внимание на идейный раскол среди жителей города, запутавшихся в исторической „неразберихе”. Василий Шульгин описывает неоднократно противоречия между самыми близкими родственниками, как в случае с семьей киевского сахарозаводчика Пятакова, где „либеральные взгляды в сердцах... сыновей расцвели и большевизмом, и монархизмом" (175). Противоречия возникали и в семьях Шульгиных:

[...] мой двоюродный брат Яков Николаевич учился в университете, примкнул к украинствующим революционерам. [...] Его сын и уже мой двоюродный племянник Александр Яковлевич Шульгин стал украинским националистом. Окончил какой-то университет, стал профессором, был министром иностранных дел в правительстве Центральной Рады и послом в Константинополе при гетмане Скоропадском (35-36).

Вспоминая о киевских реалиях, Василий Шульгин не пытался искажать картину родного города, замечая лишь единомышленников, отданных общерусской идее. Не стремился он также идеализировать сторонников русского Киева, что особо видно в описании Белого движения, разложение которого редактор „Киевлянина” наблюдал в 1919 году. Отвечая на упрек одного из знакомых (произнесенный осенью 1919 г.), что в статьях Владимира Витальевича нет той прежней силы, Шульгин соглашается:

И действительно, ее уже не было. Я сам это понимал. Откуда она могла взяться? Я писал, что мы не отдадим Киева ни красным, ни жовто-блокитным. Но я не чувствовал уверенности. Да и на внутреннем фронте тоже было невесело (252).

Несмотря на разочарование и пессимизм, Шульгин до последнего дня оставался в Киеве и покинул город пешком в декабре 1919 года, когда большевики были уже в самом центре, у Софийского собора ${ }^{17}$. Стремление как можно дольше оставаться в родном городе и здесь дало о себе знать.

Личность Василия Шульгина доказывает сегодня, насколько сложной и неоднозначной является история Киева (и всей Украины) в XX веке. Мировосприятие киевлянина, любящего родную

17 Последние часы Шульгина в Киеве и последующий выход из города описаны в главе Догорание. См. В. Шульгин, Тени, которые проходят, указ. соч., с. 262-265. 
Малороссию (определение самого Шульгина), а также сознательно подчеркивающего и отстаивающего свою и ее русскость, сегодня может показаться парадоксом. Однако позиция Василия Шульгина не была сто лет назад исключением - подобные взгляды выражали многие образованные киевляне. И опять же, представлять их всех в качестве бессознательных жертв имперской политики России было бы чрезмерным упрощением. Шульгин и ему подобные могут вызвать затруднения в сегодняшних украинских реалиях, в которых четко прослеживаются попытки разделить и противопоставить друг другу свое, родное украинское и чужеродное, насажденное русское. Ввиду „несовместимости” с украинской точки зрения определений „свой” и „русский”, Шульгина, которого сложно назвать "чужим", приходиться либо игнорировать, либо называть украинцем. Примером второго подхода является статья Андрея Бессмертного-Анзимирова Василь Шульгін і його місие $b$ історії України, опубликованная в рамках интернет-проекта авторитетного издания „День"18:

Життєвий шлях Шульгіна показує, що всупереч усім його монархічним і імперським переконанням він помер українцем. У його душі перемогла не Росія, а Україна ${ }^{19}$.

С данной точкой зрения сложно согласиться, учитывая все написанное и сказанное Василием Шульгиным. Впрочем, в качестве "ответа" украинскому публицисту в завершение нашей статьи приведем еще один фрагмент воспоминаний. Когда в 1918 г. немцы вызвали Шульгина на допрос в связи с тем, что он в знак протеста против немецкой оккупации Киева закрыл газету, имел место следующий разговор:

Я явился, и меня принял полковник фон Лешник. Он говорил по-русски и начал так:

- Я прочел вашу статью. Почему вы закрыли газету? Зачем вы так ставите вопрос? Ведь вы украинец.

- Вам угодно называть меня украинцем, но я русский. Германия состоит в войне с Россией, а значит, все ясно. Мне кажется, господин полковник, что ваша фамилия славянского происхождения.

18 Проект „Україна Incognita”, по заявлению его создателей, направлен на формирование „неискаженной исторической памяти украинцев”. См. Про проект "Україна Incognita", [в:] электронный ресурс: http://incognita.day.kiev.ua/about.html (27.01.2018).

19 „Жизненный путь Шульгина показывает, что, вопреки всем его монархическим и имперским убеждениям, он умер украинцем. В его душе победила не Россия, а Украина" [перевод - А. Б.]. - А. Безсмертний-Анзіміров, Василь Шульгін i його місие В історії України, [в:] электронный ресурс: http://incognita.day.kiev.ua/ vasil-shulgin-i-jogo-miscze-v-istoriyi-ukrayini.html (27.01.2018). 
- Да, но меня захватила идея германской империи, и я немец.

- Точно так же и я. Меня захватила идея русской империи, и я русский (193).

Приведенные слова, продиктованные Шульгиным в конце жизни, достаточно однозначно подытоживают вопрос его идентичности и отношения к событиям, происходящим в Киеве после 1917 года. И если мнение, что публицист и мемуарист „умер украинцем" вызывает определенные сомнения, то однозначно можно сказать, что Василий Витальевич Шульгин всю жизнь оставался киевлянином.

\section{Библиография}

Бабков Д., Государственные и национальные проблемы В мировоззрении В. В. Шульгина В 1917-1939 годах, Москва 2012.

Бабков Д., Политическая публицистика В. В. Шульгина $b$ период гражданской войны и эмиграциии, „Вопросы истории” 2008, № 3.

Безсмертний-Анзіміров А., Василь Шульгін і його місие $b$ історії Украӥни, [в:] электронный ресурс: http://incognita.day.kiev.ua/vasil-shulgin-i-jogo-miscze-v-istoriyiukrayini.html (27.01.2018).

Бортневский В., Неизвестный автографр В. В. Шульгина, [в:] электронный ресурс: http://xxl3.ru/kadeti/pomnim3.htm\#shulgin (27.01.2018).

Забужко О., Цей проклятий „кВартирныи вопрос”, [в:] электронный ресурс: https://www.radiosvoboda.org/a/27079412.html (27.01.2018).

Иоффе Г., Василий Шульгин, „Новый журнал” 2006, № 242-243.

Лурье Л., Бедная Катя, „Городское обозрение \& Галерея красивых домов и квартир" 2011, № 2, [в:] электронный ресурс: http://gorod.spb.ru/articles/1305 (27.01.2018).

Провідники духовності в Україні, ред. І. Ф. Курас, 2003, [в:] электронный ресурс: https://uchebnikionline.com/kulturologia/providniki_duhovnosti_v_ukrayini_-_kuras _if/shulgin_yakiv_mikolayovich.htm (27.01.2018).

Пученков А., Национальный вопрос в идеологии и политике южнорусского Белого движения В годы Гражданской войны. (1917-1919 гг.), Санкт-Петербург 2005.

Пушкин А., Евгений Онегин, [в:] Его же, Сочинения 6 трех томах, т. 3, Москва 1978.

Репников А., Христофоров В., В. В. Шульгин - последний рыиарь самодержавия. Новые документы из архива ФСБ, „Новая и новейшая история” 2003, № 4.

Шульгин В., Дорогие читатели!, „Киевлянин” 1917, № 89.

Шульгин В., По телеграфу из Петрограда, „Киевлянин” 1917, № 96.

Шульгин В., Тени, которые проходят, Санкт-Петербург 2012.

Шульгин В., Украина, „Киевлянин” 1912, № 4. 
